\title{
Assessing Administrative Reform in India
}

\author{
Kuldeep Mathur ${ }^{1} \cdot$ Navdeep Mathur ${ }^{1}$
}

Received: 8 October 2016/Accepted: 3 January 2017/Published online: 9 February 2017

(C) Fudan University and Springer Science+Business Media Singapore 2017

\begin{abstract}
This paper outlines trends in efforts at administrative reform in India. It spans the shift of ideological paradigm of the Indian political economy. While the pre1991 period was marked by a waning Statism, structural economic reforms marked a shift towards neo-liberal public management in the post 1991 period. This shift made the role of markets more salient as a framework for public services, in contrast to traditional perspectives of public administration. In the last two decades, even though some concern regarding administrative reform was expressed, substantive change took place outside the realm of the state machinery while blurring the borders between private and public institutions in delivering public services. The current political regime has added emphasis in the direction of using the bureaucracy to promote marketization and privatization in the allocation of public resources.
\end{abstract}

Keywords Administrative reform - Public management $\cdot$ Public private boundaries $\cdot$ Neoliberal governance

\section{Introduction}

Concern about reforming public administration in India is not something new. What is new is the context in which it is being talked about today. The period beginning from 1991 is marked by the emergence of a liberal economic regime that is attempting to dismantle the centrally directed framework of economic development. It is also the beginning of the period when the international multilateral agencies have begun attaching conditionalities while giving aid. These conditionalities initially were limited to prescriptions on how the aid would be administered but have gradually broadened their scope by suggesting reforms in overall framework of

Navdeep Mathur

navdeep@iima.ac.in

1 Indian Institute of Management, Ahmedabad, Gujarat 380015, India 
governance itself. This is happening all over the world. Reform is in the air and no country is left out of this global discourse. Changes in the intellectual climate that provided a new understanding of the role and scope of public administration propels this discourse while 'Reinventing Government' summarises and celebrates this new understanding.

When talking about the failure of the planned strategy of development, particularly in the achievements of the various 5-year plans, the discussion usually veers around the impediments created by the inherited bureaucratic and administrative system of the British colonial days. The planners were quite conscious of the need for a different system to implement the planned objectives of development and wrote so in chapters of several plan documents. The government responded to this concern by appointing many committees to suggest changes in the system. In this expression of concern for administrative reform, public administration emerged as an academic discipline in India and provided the intellectual background for suggestions to improve public administration in practice. Intellectual analysis of the problems of public administration and nature of efforts at administrative reform are closely linked. The purpose of this paper is to examine the efforts at administrative reform in India and analyse the context in which they were made. It is debatable whether these efforts made any substantive impact on the practice of public administration in India. The second part of the paper will attempt to discuss some reasons why these efforts merely chanted the same litany of complaints against an ineffective administration without making any headway on the ground. Finally, the paper will focus on the challenges facing the government in the post economic reform period to see whether the experience will be different from the earlier one.

\section{The Colonial Legacy}

The building blocks for the study of public administration in India were provided by the contribution of many British administrators mainly belonging to the Indian Civil Service. Many of these contributions were in the nature memoirs and apart from being descriptive of the customs and manners of Indian society were rich in detail of the working of the British Indian administration. One of the major outcomes of these writings was the creation of what has come to be known as the 'ICS mythology' and a romantic view of field administration. One of the premier representatives of the most romanticised version of the role of the ICS is 'The Guardians', the second volume of Philip Woodruff's well known study 'The Men Who Ruled India' (1954). Even though Woodruff asserted that the term guardians was his own, several writers (ex-civil servants) joined him in perpetuating the myth of the altruistic characteristics of the ICS in which platonic guardianship and men being of superior virtue dominated. The love of outdoor life, commitment to the district and the welfare of its population, courage and daring in decision making, independence and integrity were among the many other virtues that the ICS seemed to possess. The Indian members of the ICS helped in perpetuating these myths through their own writings in the post-independence era (see Chettur 1964; Panjabi 1965). 
A number of scholars particularly British also joined in this chorus. A rhetorical question like the following was asked: "How is it, that 760 British members of the ruling Indian Civil Service could as late as 1939, in the face of the massive force of India national movement led by Gandhi, held down 378 million Indians?" (quoted in Spangenburg 1976:4). Such a question implied that the British had the skills to govern India. This assertion was based on three essential myths: a. the myth of the popularity of the civil service as a profession that attracted the best minds; $b$. the myth of efficiency in administering India; and c. the myth of sacrificial esprit de corps of the ICS which ostensibly infused the government with the primary concern of working for the welfare of the people.

For the British, the perpetuation of this myth served many functions. It came as a defence of British imperialism in the court of world public opinion. Teddy Roosevelt, at the end of his second term as President in 1909, cited British administration in India as a prime example of overwhelming advancement achieved as a result of white or European rule among the "peoples who dwell in the darker corners of the earth' (Spangenburg 1976:7). It also helped assuage internal opinion in England reassuring the British ruling classes that the British rule was beneficial to India.

This myth not only survived but also prospered many years after independence. The basic framework of administration continued as if the colonial administrators had not departed at all. As an Indian journalist later remarked, 'this would be unbelievable were it not true', but Nehru and his colleagues sought to build 'a new India, a more egalitarian society.... through the agency of those who had been the trained servants of imperialism - it is as if Lenin, on arrival in Russia, had promptly mustered the support of White Russians he could find' (quoted in Potter 1986:2). What is paradoxical is that this myth has persisted well on to the 1980s and has resulted in the general posture adopted by the civil servants and professionals in dealing with politicians and development processes.

The inability of national leadership to bring about change in the early 1950s set the old system of administration in firm saddle. Nehru writing much before independence had said, 'I am quite sure that no new order can be built up in India so long as the spirit of the ICS pervades our administration and our public services. That spirit of authoritarianism...cannot exist with freedom.... Therefore, it seems essential that the ICS and similar services must disappear completely as such before we can start real work on a new order' (Nehru 1953:8). In the spring of 1964, Nehru was asked at a private meeting with some friends what he considered to be his greatest failure as India's first Prime Minister. He reportedly replied "I could not change the administration, it is still colonial administration' (quoted in Potter 1986:2).

The essential point is that the British administration upheld by its many myths survived and entrenched itself well into the post-colonial period. However, the introduction of Community Development Programme first raised the demand of a new type of administrator who would be unrelated to the colonial one. The administrators began to be told that a programme of social change like that of community development could not be implemented successfully through colonial 
administrative structures, procedures. The administrators were exhorted to identify with rural life.

\section{The Reform Effort}

The emphasis on the schism between the old and the new gained scholarly attention really after Paul Appleby, a Professor at Syracuse University, was invited by the Government of India to report on Indian administration. He expressed the view that there was a dichotomy between bureaucratic dispositions and development needs in India (Appleby 1953). Some Ford Foundation experts reinforced this view when they recalled their work in community development programmes, commented that '...the inadequacies of the Indian bureaucracy are not due to the fact that it is bureaucracy but due to considerable fact that it carries too much baggage from the past' (Taylor et al. 1966:579). This view gained further support when scholars like La Palombara (1963:1) wrote 'Public Administration steeped in the tradition of the Indian Civil Service may be less useful as developmental administrators than those who are not so rigidly tied to the notions of bureaucratic status, hierarch and impartiality'.

Simultaneously, the development administration movement was gaining momentum within the discipline of public administration. This thrust had several dimensions among whom at least two dominated. One was of professionalisation of administration through the acceptance of a management orientation. It was argued that management techniques and tools could be used successfully to improve the implementation of development programmes and administrators must spent significant time and effort in learning these techniques and applying them. Improved education and training became the core efforts at professionalisation.

Another dimension of this movement had to do with change of behavioural orientation of public administrators. This focus was aptly summed up by a leading contributor when he suggested that only by becoming less oligarchic, less technocratic, less stratified, closer to the administered and the managed, more deeply rooted in the aspirations and needs of the ordinary people, only by such changes can public service become a force with which the people of a developing country may identify and they may have justified confidence (Gross 1974).

It was this message that the academics and consultants from the West, particularly the United States, brought to India and through financial and technical aid influenced the theory and practice of public administration in the country. The Ford Foundation alone spent US\$360,400 in grants to institutions and US\$76,000 in providing consultants and specialists to improve public administration in India during 1951-62 (Braibanti 1966:148). An important consequence of this financial and technical aid as well as the intellectual thrust of development administration was that it began to be believed that change in the colonial administrative system lies in changing the behaviour and the professional capacity of the individual bureaucrat. This was possible through education and training programmes. Training institutions proliferated and studies that supported this broad argument multiplied. Large number of scholars was attracted to the field of development administration, 
motivated not only by scholarly reasons but also by the belief that administration was the instrument of change and administrative behaviour could be transformed without structural changes in the colonial administrative structure and procedure.

During the period 1952-1966, policies of administrative reform were heavily influenced by the developments in disciplinary understanding of public administration in the United States and the perceptions of these academics and consultants of the problems of administration in developing countries, such as India. It was at the request of the Government of India that Ford Foundation readily made available Prof. Paul Appleby of Syracuse University to suggest changes in the administrative system in the country. He presented a Report in 1953 that set the tone of much of what was done later. What is important to note is that until 1966, no other committee was appointed to have a broad look at administration. As a consequence of the Appleby Report Organization and Methods, divisions were established in each government department to take care of the everyday issues of procedural efficiency. Another recommendation of Paul Appleby to establish an Indian Institute of Public Administration was also accepted. This Institute was supposed to take up reform measures on a continuous basis but based on research studies.

In operational terms, the effort at administrative reform during this period was based on education and training programmes for civil servants. The international aid was extensively utilised for this purpose. Large number of training institutions was established at both the central as well as state levels. The pattern of recruitment to the higher civil services was changed, and the training system was also reformed.

A comprehensive examination of the Indian administrative system was undertaken with the appointment of Administrative Reforms Commission in 1966. It was patterned after the Hoover Commission of the US having a political and civil servant membership with experts coming into write reports after study and research. The Commission worked over a period of four years making a total of 581 recommendations (Maheshwari 1993:116). Little impact of the Commission was felt; no recommendations of consequence were accepted. The politicians who became members did not command prestige and influence with the government of the day. As a matter of fact, the government itself was in a flux. Lal Bahadur Shastri, the Prime Minister, who had appointed the Commission in 1965, suddenly died and Indira Gandhi took over. For the years up to 1971, she was fighting for her political survival, attending to crises and did not find time to reflect on administrative change. When the Commission finished its tasks, the country was facing a war for the liberation of Bangladesh and subsequently was caught in the turmoil of national emergency. The ruling party was comfortable working with the existing administrative system and reforming it was not on the agenda of the political parties in opposition. The Administrative Reforms Commission just faded away leaving behind a pile of reports and frustration at the national inability to reform a colonial administrative system.

If during the early period of India's independence, administration was seen as instrument of change, the period after the Third Plan 1961-66; it began to be to be seen as an impediment to development. Plan performance had been poor and the policy makers saw lack of effective administration as major contributing factor. As a matter of fact, in 1969, the Congress party itself raised the issue of the inability of 
a neutral civil service to implement goals of development. It pleaded for a committed civil service. The question 'committed to what' was left open. A fierce debate followed in which retired and serving bureaucrats participated freely (see Dubhashi 1971; Chaturvedi 1971; Committed Civil Service 1973). No formal change took place but the practice of shifting bureaucrats on demands of political leadership began a characteristic that is spread widely in the system today. The period of emergency when loyalty became an important criterion for holding a pivotal position in government was replicated when Janata Party came to power defeating the Congress and Mrs. Gandhi. The return of the Congress and defeat of Janata Party in 1980 signalled the beginning of the process again. The practice has spawned what is colloquially known as 'transfer industry' and the central government has begun to reflect what was confined to states only (Banik 2001). Formal acceptance of this idea would have transformed the role of the civil service but this did not happen. What could not be formalised was openly accepted in practice.

\section{Failure of Reform Effort}

One possible reason that administrative reform failed to make a dent into the inherited administrative system was the weakness on the conceptual front. No alternative was offered. What was offered was ways to improve the existing system. In addition, these ways were too inconsequential. Intellectually, adherence to the Weberian model and Taylorian norms of work considerably constrained the generation of alternatives. Overwhelming academic response to administrative problems was through analyses of structural attributes that caused bottlenecks in coordination or communication, or of the behavioural irritants that led to friction either in a team of bureaucrats only or one of bureaucrats and politicians. The prescription was already decided and not questioned, and therefore, when the problems persisted, the solution was to increase the dosage of further division of labour, and specialization or tighten controls through improved lines of communications and authority.

The problem was that the empirical insights did not reflect the dominant concerns in the intellectual study of public administration, where Weberian influences held the attention of most scholars who explained variations in administrative performance by examining issues of neutrality, training and professionalism, structure of hierarchies, and processes of work and behavioural orientations. Another source of explanation was the emphasis on the abilities and qualities of an individual and the belief that it was an individual who made the difference whatever be the structural constraints. A development oriented bureaucrat implemented programmes well in spite of the prevailing administrative system. The memoirs of the civil servants are replete with illustrations that show how they as individuals dealt with new political issues (see for a recent example, Dar 1999).

Little concern for administrative reform was expressed in the 1970s and later. Severe indictment of the civil service was made by the Shah Commission of Inquiry, which reported that they carried out instructions from politicians and 
administrative heads on personal and political considerations. There were many cases, where officers curried favour with politicians by doing what they thought the people in authority desired. In short, the evidence showed, as a journalist remarked, "(the Emergency was) the high water-mark of the politicians victory in the long drawn out struggle against the civil service" (quoted in Potter 1986:157).

In the last two decades, the story of administration as an impediment to development has taken a drastic turn. If the beginning of the Plan period saw an effort to strengthen state intervention as recipe for triggering development, the 1980s ended with disastrous accounts of failures of regulatory and interventionist states and with strong pleas to dismantle state machinery and its roles. Neo-liberal economic theory tended to build its case on how rulers extract resources and invest them. It argued that rulers in interventionist states tend to use resources for their own benefit to the detriment of the development of their societies. The argument of state failure was based on how monopoly rents are created through the imposition of regulation and control of the economy. Political pressures dominate economic policy formulation and execution. A consequence of this system is that government machinery is used for personal interests. The policy recommendation that follows from this diagnosis is to minimize state intervention and to rely increasingly on markets for resource use and allocation.

\section{Renewed Efforts}

The above diagnosis of the failure of government in development led to rethinking about the structure and role of public administration. A kind of revolution occurred and the focus shifted from control of bureaucracy and delivery of goods and services to increasingly privatise government and shape its role as an entrepreneur competing with other social groups and institutions to provide goods and services to the citizens. The book of Osborne and Gaebler 'Reinventing Government' (1992) was a landmark in the growth of ideas that have sought to build a New Public Administration. Public administration was admonished to 'steer rather than row' for 'those who steer the boat have far more power than those who row it' (Osborne and Gaebler 1992:32). Since then, these ideas have swept across the world and the international/multilateral agencies have used them to influence public management of their economic aid programmes. The common theme in the myriad applications of these ideas has been the use of market mechanisms and terminology, in which the relationship of public agencies and their customers is understood as based on selfinterest, involving transactions similar to those occurring in the market place. Public managers are urged to steer not row their organizations and they are challenged to find new and innovative ways to achieve results or to privatise functions previously provided by government (Denhardt and Denhardt 2000:550). In this new world, the primary role of government is not merely to direct the actions of the public through regulation and decree, nor is it merely to establish a set of rules and incentives through which people will be guided in the proper direction. Rather government becomes another player in the process of moving society in one direction or another. Where traditionally government has responded to needs by saying "yes, we can 
provide service" or "no, we cannot," the new public service suggests that elected officials and public managers should respond to the requests of the citizens by saying "let us work together to figure out what we are going to do, and then make it happen" (Denhardt and Denhardt 2000:554).

Operationally, these ideas have advocated: a. managerially oriented administration; b. reducing public budgets; c. downsizing the government; d. selective privatization of public enterprises; e. contracting out of services; f. decentralization; g. transparency and accountability; and h. emphasis on civil society institutions and non-governmental organizations to deliver goods and services.

When India embarked upon an ambitious programme of economic reform in 1991, the ideas about public administration reform had already entered the package of aid that was promised by the World Bank and the IMF. It will be fair to say that they were reflecting a change in the disciplinary thrusts of public administration too. Country after country was deciding to change and reform their governments. There is little doubt that this change was being triggered by the wave of policies of structural adjustment and liberalization prompted by a new globalization set in after the collapse of Soviet Union. Therefore, while administrative reforms are profoundly domestic issues, the fact that they are being seen as part of package of the 'new deal' makes them open to external pressures and influences. Reform is stylish today, and there is more than a single reason why it is so. Technological changes are calling for managerial changes. The information technology with its computer base has caught the imagination of both administrators and politicians. Demands for greater decentralization are being met because of change in the political scenario. People's groups are becoming more aware of their rights and demanding improved government services that are transparent and accountable to them. This is apart from the influence that the international financial agencies are exercising on government to reform to be eligible for more loan/aid and directly funding NGOs to implement development programmes.

The effort at reducing the size of government began with successive budgets presented by the Union Finance Minister from 1992. The imperative need was to reduce the fiscal deficit and cut down on unproductive expenditure. In a bid to bring about fiscal prudence and austerity, the Centre imposed a $10 \%$ cut across the board in the number of sanctioned posts as on January 1, 1992. The Fifth Pay Commission that submitted its report contained a recommendation for a whopping one-third cut in government size in 10 years. The downsizing exercise was later taken up by the Expenditure Commission, which further recommended cut in the number of sanctioned posts as on January 1, 2000. As a matter of fact, instructions for cutting sanctioned posts were renewed in 2000 directing a $10 \%$ reduction in the posts created between 1992 and 1999 (Raina 2002). Statistics maintained by the Ministry of Finance show that pay and allowances bill of the central government was Rs. 33,977.79 crores for the year 1999-2000 showing a hike of Rs. 31,560.19 crores over the previous year. The number of central government civilian regular employees was 38.55 lakhs on March 1, 2000 down from 39.07 lakhs on March 31, 1999. There had been a decrease of 51,605 posts or of just $1.32 \%$ (Mishra 2002). As one can see, there is very little impact of these efforts. 
In 1996, a Chief Secretaries Conference reiterated the popular policy prescriptions for a responsive and effective administration. The Conference recognised that the public image of the bureaucracy was one of inaccessibility, indifference, procedure orientation, poor quality and sluggishness, corruption proneness, and non-accountability for result (Government of India 1997a:1). The Fifth Pay Commission (Government of India 1997b) took the concerns of the Chief Secretaries listed among many of its recommendations the need to downsize the government and to bring about greater transparency and openness in government.

Two developments of significance took place. A Chief Minister's Conference endorsed the issue of transparency through citizens' right to information in 1997. In addition, the concept of Citizen's Charter took shape. Both were a follow-up on the recommendations of the Pay Commission, which in turn was in a way responding to grassroots demands in villages of Rajasthan.

A people's organization in Rajasthan, known as Mazdoor Kisan Shakti Sangathan (MKSS), has been in the vanguard of this struggle and forced government to respond to the demands of information and accountability. As documented in Roy et al. (2001), the people began to understand that their livelihood, wages, and employment depended a great deal on the investments made by the government as a development agency. If these benefits were not coming, then they had the right to know where the investment occurred and how much of it was actually spent. The right to economic well being got translated into right to information. As Roy et al. (Ibid) point out, the struggle became for 'hamara paisa hamara hisab'. In other words, accountability became a critical issue in the public hearings organized in five blocks of four districts. Four demands were made: transparency of development spending, accountability, sanctity of social audit, and redressal. This campaign began in 1994 and gradually gained momentum spreading to the most parts of the state. It reached to the level, where assurances had to be provided by the Chief Minister.

The essence of the campaign that steamrollered into a movement for right to information was the jan sunwai (public hearing), where villagers assembled to testify whether the public works that have been met out of the expenditures certified by the government actually exist or not. The first Jan sunwai was held in a village of Kot Kirana in 1994. Since then, they have caught the imagination of the MKSS that has held them at several places. Beawar was the scene of a major event in April 1996. It was followed by a 40-day dharna in which activists were fed and sheltered by the public. Another 53-day dharna was organized at Jaipur (see Bunker Roy, The Asian Age 30 May 2001). The Rajasthan government responded reluctantly, but the Chief Minister ultimately announced that the people had the right to demand and receive details of expenditure on development works in their villages.

Three months after the event in Beawar, politicians, jurists, former bureaucrats, academics, and others joined in demanding right to information legislation at a conference in New Delhi. A committee under the chairmanship of Justice PB Sawant was authorised to draft a model bill. The central government too came under pressure to introduce legislation in the Parliament that could be followed by the states. 
Government of India sets up a Working Group on Right to Information and Promotion of Open and Transparent Government in 1997. The terms of reference of the Group included the examination of feasibility and need to introduce a full fledged Right to Information Act so as to meet the needs of open and responsive government. The Working Group placed its tasks within the broad framework of democracy and accountability and emphasised, 'democracy means choice, and a sound, and informed choice is possible only on the basis of knowledge' (Working Group Report 1997:3). It also argued that transparency and openness in functioning have a cleansing effect on the operations of public agencies and approvingly quoted the saying that sunlight is the best disinfectant.

The Working Group accepted the following broad principles to the formulation of the legislation:

(a) Disclosure of information should be the rule and secrecy the exception.

(b) The exceptions should be clearly defined.

(c) There should be an independent mechanism for adjudication of disputes between the citizens and public authorities.

A draft bill has been prepared which was put to public debate and now the proposed legislation is lying with the Parliament for approval.

Transparency in government also became an issue on the agenda of the Conference of Chief Ministers held on 24 May 1997. The conference issued a statement that provided an Action Plan for Effective and Responsive Government at the Central and State levels. In this statement, the Chief Ministers recognised that secrecy and lack of openness in transactions are largely responsible for corruption in official dealings. The government set for itself a time limit of three months to ensure easy access of the people to all information relating to Government activities and decisions, except to the extent required to be excluded on specific grounds, such as national security. The statement also gave an assurance that the Report of the Working Group on Right to Information would be quickly examined and legislation introduced before the end of 1997. Political events have taken over, and the Act has yet to come into existence.

It is clear from the above that this dimension of administrative reform that stresses transparency and right to information is an issue that has been spearheaded by the people. It is not a change attempted by a well meaning and benign government. However, the struggle has not yet been enough to get legislation passed by the Parliament or the state legislatures. There has been resistance not only from the political leaders who swear by the name of democracy but also from the bureaucrats whose norms of work had been dictated by secrecy and confidentiality. The Rajasthan experience has shown that even the local level administrators have found ways to thwart attempts at opening the administration closest to the people for scrutiny.

The reason of resistance is not far to seek. Much of the corruption that occurs in official dealings takes place under the cover of state sanctioned secrecy. The norm has been to keep information away from the people on the pretext of guarding public interest. Large number of national scams occurs, because no one knows what 
is happening in closets of government. At the local level, even the information on muster rolls is deemed to be confidential. Therefore, the movement for information has as its genesis the fight against corruption and demand for accountability. The muster rolls carried false name in Rajasthan villages and this could be identified only by the local people and not by the audit parties sent by the government. It is for this reason that the proposed bill does not provide the full opening of the file of decisions to the public. Who advises what will not be told. The recent incident, widely reported in the press, when the Urban Development Minister's order for placing a particular file on land deals for public scrutiny was reversed by the bureaucrats shows the fear of open decision making (see Statesman 1998).

Information then is also associated with power government exercises. By restricting information, people in government become more powerful than those who are outside it. Thus, demand for transparency and information is also about sharing of power. It is possible to misuse power when it is concentrated rather than when it is shared among a broader stream of people. As information grows, the arbitrariness of government tends to reduce. However, the resistance from the local level functionaries is growing in response to the Jan sunwais held by the MKSS is Rajasthan. A recent newspaper report of The Hindu (March 13, 2002) mentions how over 240 sarpanchas have organized themselves and waited on the Chief Minister to resist further sunwais.

It is this kind of resistance that has delayed the actual passage of the bill. It is necessary for the parliament to take early steps to pass the law on the right to information. Godbole (2001:1423) rightfully fears that longer the delay in the passage of the Bill, the weaker and more anemic, it is likely to be. Each successive draft bill on the subject prepared by the central government is a watered down version of the earlier bill and is a bundle of compromises affected to accommodate the stiff opposition to the proposed measures at the political and bureaucratic levels.

The citizen's right to information has been coupled with the idea of Citizen's Charter. The aim of the charter is to make available to the citizen the information to demand accountability, transparency, and quality and choice of services by the government departments. It was first introduced in Britain in 1991 to streamline administration and make it citizen friendly. A Core group has been set up under the Chairmanship of Secretary (Personnel) for monitoring the progress of initiatives taken by Ministries/Departments with a substantial public interface. So far, 61 charters have been formulated which include 27 Charters for public sector banks and 4 Charters for hospitals (Agnihotri 2000:126). For lack of effective monitoring, this has remained a paper exercise.

\section{Concluding Remarks}

Some lessons can be drawn from the experience of administrative reforms in India. Those who resisted change have derived great inspiration from the support that Sardar Patel, India's first Home Minister, gave in saving the ICS and the steel frame. At the time of India's partition, he warned that chaos would result if the Civil Service were removed from the scene. Nehru agreed and civil service reform was 
not on high priority at the time when riots and uprisings had to be handled to maintain the integrity of the country. Since then, one crisis or the other has taken precedence and administrative reform commanded little attention. When it did, it was an administrative matter to be handled by the administrators themselves. The committees and commissions that came to review administration had administrators themselves as members. The administrators for purposes of feasibility of implementation processed even the recommendations of the Administrative Reforms Commission, 1966-1970, that had a wide range of consultations with people from various professions. One reason could be that the understanding of public administration was heavily influenced by a paradigm that was inward looking and perceived bureaucracy as a more or less autonomous instrument of implementing development policies and programmes.

Another could be that political leadership saw advantage in maintaining the status quo while continuing to articulate the need for radical reforms for public rhetoric. Mrs. Gandhi and her group quickly saw that civil service could be 'committed' while continuing the public posture of neutrality. The Emergency period and the subsequent years of 'transfer industry' are ample evidence of keeping to form rather than substance. Even in questions of downsizing the government, a mantra from 1992, the same evidence is forthcoming. The A level positions continue to remain largely untouched, while all reforms-reduction of positions or contracting out principles-are targeted at lower levels. The IAS or the IPS that has held critical positions in government has never been under scrutiny for reforms in spite of public outcry against their role and behaviour. The only time that a serious attempt was made was when the Administrative Reforms Commission made the recommendation of delimiting areas of specialization in the secretariat and manning, these areas from personnel drawn from all sources through a mid-career competitive to include more specialists in the higher positions was made. This recommendation was scuttled and not accepted by the Government when the IAS itself sought specialization through training and postings.

In the ultimate analysis, civil service reform in India has neither enhanced efficiency nor the accountability of the civil service in any meaningful manner. As far as the common citizen is concerned, it has not been effective. If Maheshwari (1972:55) commented that India's effort at reform have amounted to correction slips to the inherited system, Das (1998:213) himself an IAS officer, has gone a step further to indict the reform effort, around a quarter of a century later, by saying that they were not even correction slips-they were more in the nature of endorsement slips. Probably, the present time of structural adjustment, liberalization, technological imperatives, and grassroots pressures may provide the best confluence of forces that can break bureaucratic resistance and promote political will to make the administrative system more open to reform and change.

The impact of such a confluence of forces is not without risks, however. The global advocates of reform have assumed that one size fits all and any government could be improved by the magic of market, privatization, participation, and efficiency. However, the expectations of people of their governments are different in different societies and they are critical in redesigning reform activities. Reinventing government in US is based on different assumptions and these may not even hold in 
UK. As Peters (2001:167) points out, "the central problem for implementing public management reforms in developing countries is that their success to some extent depends on the existence of public service values and practices that support accountability and effective management". Deregulation and granting autonomy may mean that the empowered decision makers may use the new found freedom to serve themselves rather than the public.

India faces the major challenge of redesigning an administrative system can sustain itself in an environment of globalization and economic reform. The earlier efforts were partly failures, because they assumed an image of the administrative system that was divorced from reality. It was rigid for most people but very flexible for the privileged among them. Rules were flouted with impunity, privatization of public office was common, and procedures were discarded at many personal pretexts. The classic Riggsian formalism was at work. It is the common citizen that lost confidence in administration and this has to be restored first. This cannot come about only through tinkering with administrative design but challenges the basic issues of governance itself.

\section{Last Pages}

As we have attempted to show administrative reform movement in India has not been lacking in ideas and suggestions. Numerous committees and commissions have been set up with experienced public affairs experts and technocrats at their helm, but little forward moves have been undertaken.

The paradox is that all Prime Ministers taking office have expressed concerns about bureaucratic rigidity and archaic procedures that cannot fulfill people's aspirations and their developmental needs. However, reform has not followed.

The first Prime Minister Jawaharlal Nehru had expressed some strong views even before independence when he wrote in his autobiography "I am quite sure that no new order can be built up in India so long as the spirit of the ICS pervades our administration and our services. That spirit of authoritarianism.... cannot exist with freedom...".

Successive Prime Ministers have expressed similar concerns when they have assumed office. Nehru has already been mentioned above. Assuming the highest office Mrs. Indira Gandhi said in 1966 what India needed today was a 'revolution in administrative system' and a year later declared that 'if a large proportion of the investment we have made under the plans remains unutilized, the cause is to be found in administrative shortcomings'. Rajiv Gandhi was more blunt and forthright when in a speech in Bombay, he said that 'we have government servants who do not serve but oppress the poor.. they have no work ethics, no feeling for public cause, no involvement in the future of the nation..' (quoted in Mathur 2014:198). AB Vajpayee addressing the National Development Council in 1999 voiced similar sentiments when he said that' people often perceive the bureaucracy as an agent of exploitation rather than provider of service. Corruption has become low-risk high reward activity (ibid:198). Prime Minister Manmohan Singh complained on assuming office in 2004 that 'I am convinced that government at every level is 
not adequately equipped and attuned to deal with it (social and economic change) and meet the aspirations of the people. To be able to do so we require the reform of government and of public institutions' (quoted in Mathur 2005:56). Possibly, it was this comment that led to the appointment of the Second Administrative Reforms Commission by his government in 2005 .

The newly elected Prime Minister (2014) Narendra Modi had entirely a different approach towards bureaucracy. He has not commented on its failings but has sought its support in implementing his developmental agenda. In a meeting with 77 top bureaucrats (Secretaries to Government of India), the Prime Minister expressed 'full faith in their commitment and competence to build a better future of the country' (Times of India 4 June, 2014). He exhorted them to take decisions without fear or favour while continuing the practice of appointing chosen bureaucrats to critical positions in government. He also encouraged them to have direct links with his office and not necessarily through the Minister who headed their ministries. ${ }^{1}$

In keeping with this overture, the Prime Minister now keeps himself in direct touch with civil servants in states and central ministries through monthly meetings conducted in tele-conferencing mode. He reviews projects, gives directions to remove obstacles, reduces red tape, or improves coordination. The ministers in charge of the relevant portfolios are kept out of these meetings. This monitoring platform has been named PRAGATI (Proactive Governance and Timely Implementation). Projects are treated on a case by case basis, and no effort is made for systemic change. It is this process of interacting directly with senior members of civil service and empowering the Prime Minister's Office that has led to the charge of centralization of powers by the Prime Minister. ${ }^{2}$

In the last 2 years (2014-2016), there has been little discussion of reform within government. There is increasing reliance on private management practices and technology to raise efficiency in the delivery of public services. For introducing this change, the government is relying on the bureaucrats themselves, and thus, the effort is of training and capacity building. Strong belief in liberal market economy, the government is placing great faith in outsourcing of services, public-private partnerships and external private consultants to guide the implementation of many policies.

Thus what is happening is that administrative reform as such is on the back burner which means that the role of bureaucracy particularly the role of its higher level members has increased and not diminished in the new dispensation. Higher level bureaucrats are beholden to the Prime Minister's Office for reporting their

\footnotetext{
1 It has been estimated that over 16 months, since Modi government came to power in 2014, 80 secretaries to Government of India have been reshuffled. This reshuffling has taken place at the behest of Prime Minister's Office not of individual Ministers. See AK Bhattacharya Winds of Change Business Standard October 4, 2015.

2 Commenting in Business Standard (February 8, 2016) Bhattacharya contends that after 20 months in power, Prime Minister Modi looks different from other Prime Ministers in his engagement with bureaucracy. He has established direct contact with senior bureaucrats, by-passing their Ministers, and monitors performance of key projects. Transfers take place more on the ability to deliver. Unlike previous incumbents, Modi has made no pretence or promise of reforming the bureaucracy.
} 
achievements and accomplishments and it is this Office that holds them accountable and the political heads of the ministries or departments that they serve.

The emerging challenge is how this effort to improve the delivery of public services through technology and private management practices can be sustained in an ossified administrative system that has been repeatedly characterized as unresponsive to state goals and new policy environment. It is administrative system that still continues to set the terms of negotiations with the private sector or rules for settlement of disputes. If these procedures, among many, are not reformed to keep pace with the private sector managerial thrust, the country faces greater prospects of administrative failures.

Acknowledgements This research was supported by a grant from the Dr. Seaker Chan Center for Comparative Political Development Studies at Fudan University.

\section{References}

Agnihotri, Vivek K. 2000. Government of India's Measures for Administrative Reforms. In Reforming administration in India, ed. V. Mehta. New Delhi: Indian Council of Social Science Research and Har Anand Publications.

Appleby, Paul. 1953. Public Administration in India Report of a Survey. Delhi, Government of India.

Banik, Dan. 2001. The transfer raj: Indian civil servants on the move. European Journal Development Research 13 (1): 106-134.

Braibanti, Ralph. 1966. Transnational inducement of administrative reform. In Approaches to Development, Politics and Change, ed. J.D. Montgomery, and W.J. Siffin. New York: McGraw-Hill.

Chaturvedi, M.K. 1971. Commitment in Civil Service. Indian Journal of Public Administration 17 (1): $40-46$.

Chettur, S.K. 1964. The Steel Frame and I. Bombay: Asia Publishing House.

Committed Civil Service: A Symposium. 1973. Seminar 168, August.

Dar, R.K. 1999. Governance and the IAS: in Search of Resilience. New Delhi: Tata McGraw Hill.

Das, S.K. 1998. Civil service reform and structural adjustment. Delhi: Oxford University Press.

Denhardt, Robert B., and J.V. Denhardt. 2000. The new public service: Serving rather than steering. Public Administration Review 60 (6): 549-559.

Dubhashi, P.R. 1971. Committed Bureaucracy. Indian Journal of Public Administration 17 (1): 33-39.

Godbole, Madhav. 2001. Right to Information: Write the Law Right. Economic and Political Weekly. 1423-1428.

Government of India. 1997. Action Plan for Effective and Responsive Administration, Statement Adopted at the Conference of Chief Ministers New Delhi.

Government of India. 1997. Report of the Working Group on Right to Information and Promotion of Open and Transparent Government, New Delhi.

Gross, P.M. 1974. The Limits of Development Administration in United Nations, Proceedings of the Inter-Regional Seminar on Organization and Administration of Development and Planning Agencies, New York, United Nations.

La Palombara, J. 1963. Bureaucracy and Political Development. Princeton: Princeton University Press. Maheshwari, S.R. 1993. Administrative Reform in India. Delhi: Jawahar Publishers.

Maheshwari, S.R. 1972. The Administrative Reforms Commission. Agra: Laxmi Narain Agarwal.

Mathur, B.P. 2005. Governance Reform for Vision India. New Delhi: Macmillan.

Mathur, B.P. 2014. Ethics for Governance Reinventing Public Services.Ghaziabad: Routledge.

Mishra, D. 2002. Quality Government for Sound Economy. Delhi: The Hindustan Times, 8 February

Nehru, Jawaharlal. 1953. An Autobiography. Oxford: Oxford University Press.

Osborne, David, and Ted Gaebler. 1992. Reinventing Government How the Entrepreneurial Spirit is Transforming the Public Sector. New Delhi: Prentice-Hall.

Panjabi, K.L. 1965. Civil Servant in India. Bombay: Bhartiya Vidya Bhawan.

Peters, Guy B. 2001. The future of governing. Lawrence: University Press of Kansas. 
Potter, David C. 1986. India's Political Administrators 1919-1983. Oxford: Clarendon Press.

Raina, Jay. 2002. Downsizing May be Uphill Task. New Delhi: The Hindustan Times.

Roy, Aruna, Nikhil Dey and Shanker Singh. 2001. Demanding Accountability Seminar, April.

Roy, Bunker. 2001. The Asian Age. New Delhi.

Spangenburg, Bradford. 1976. British Bureaucracy in India Status, Policy and the ICS, in the Late 19th Century. Delhi: Manohar Book Service.

Statesman (New Delhi) 1998. Front-page story: Bureaucrats Misled Cabinet on CVC Draft, Charges Jethmalani.

Taylor, Carl, et al. 1966. India's roots of democracy. New York: Praeger.

Woodruff, Philip. 1954. The Men Who Ruled India. London: Jonathan Cape.

Kuldeep Mathur is former Professor, Jawaharlal Nehru University, New Delhi. He held the academic chair of the Centre for Studies in Law and Governance and served as Rector at the JNU. He has also taught at the Indian Institute of Public Administration, New Delhi, and has served as a consultant for the UN and Asian Development bank.

Navdeep Mathur is on the faculty of The Public Systems Group, at the Indian Institute of Management, Ahmedabad. He has previously served as a Research Fellow at INLOGOV, School of Public Policy, University of Birmingham, UK. He was founding co-editor of Critical Policy Studies (Taylor and Francis). 